\title{
Analysis of the Influence of RMB Internationalization on the Effect of Monetary Policy
}

\author{
Yu Lei, Peng Wang \\ School of Management Engineering, Zhengzhou University, Zhengzhou 450001, China
}

Keywords: RMB; Internationalization; Monetary policy; Influence

Abstract: Along with the development of China's economy, the improvement of comprehensive national strength, the deepening of financial globalization, and the widespread use of RMB in the world, the basic conditions of RMB internationalization have been established. The internationalization of the RMB is both an opportunity and a challenge for China, and it has brought benefits to China, and it has also affected China's monetary policy. This paper combines theoretical and empirical methods to study the impact of RMB internationalization on various variables and links of China's monetary policy, and concludes how to prevent the impact of RMB internationalization on China's monetary policy, and proposes corresponding countermeasures.

\section{Introduction}

At present, there is no uniform regulation for the academic community of currency internationalization. There is no relatively complete structure in terms of the function of money. Nowadays, the international community temporarily defines it as a currency that is used beyond the boundaries of its issuing country. It will still be available to residents of other countries outside the issuing country.

After the 19th National Congress, with the continuous strengthening of China's comprehensive strength and the deepening of reform and opening up, China's economy will continue to improve and the international financial community will also have deeper integration, which will greatly enhance China's international finance. In 2016, China signed a currency swap agreement with the rest of the world, amounting to 2.57 trillion yuan. In order to realize the internationalization of the $\mathrm{RMB}$, China has already made the conditions and functions of the RMB to meet the international currency. The internationalization of the RMB has brought many benefits to China, and has also brought many influences on the effects of China's monetary policy, affecting the implementation of macroeconomic policies and the independence of the monetary system. Under the circumstance, the implementation policy of the currency will be affected by various factors, and the strengthening of the internationalization of the RMB will inevitably affect China's monetary policy. Therefore, this paper will focus on the impact of RMB internationalization on China's monetary policy and propose some countermeasures. 


\section{Literature review}

Regarding the impact of currency internationalization on the implementation of monetary policy by the state, scholars at home and abroad have conducted research from different aspects.

\subsection{Foreign research status}

Some foreign scholars believe that the US dollar has greatly weakened the independence of the US from the implementation of monetary policy in the process of internationalization. Some scholars believe that the US dollar not only lets the United States face the "Triffin problem", but also hinders the independence of monetary policy. In studying the internationalization of the yen, Japanese scholars pointed out that the internationalization of the yen will expand its external influence, especially when Japan formulates monetary policy, paying particular attention to the influence of countries in Southeast Asia. Glydon (1981) used experiments to establish a model. He believes that under the background of constant economic openness, the higher the degree of currency internationalization, the more unstable the exchange rate, and greatly affect the independence of a country's implementation of monetary policy. Vasily (1997) believes that in the case of stable exchange rate, currency internationalization will reduce the central bank's control over the base currency because of different people's preference for money; if the exchange rate is not closely watched, currency internationalization will also increase the impact of the exchange rate. The frequency of floating, which in turn affects the implementation of monetary policy (Marco Airaudo,2014).

\subsection{Status of domestic research}

Most domestic studies have suggested that the internationalization of currency has a hindrance to the implementation of monetary policy. Under the influence of RMB internationalization on China's monetary policy, Yuanfang Cao (2005) proposed that the RMB should build a return mechanism, strengthen auditing and supervision, strengthen cooperation with other countries, and implement effective monetary policies. Qinglong Zhang (2011) used the IS-LM model to analyze the impact of RMB internationalization on China's implementation of monetary policy from different perspectives. Yong Wang (2003) believes that China's financial market is easily manipulated by foreign illegal speculators, which in turn affects the implementation of China's monetary policy. Qinglong Zhang (2005) proposed that a country's monetary policy will reduce the influence of policies on the currency as the degree of internationalization strengthens. Kai Jiang (2010) pointed out that the strengthening of the internationalization of the RMB will increase the difficulty of the government's control over currency and weaken the state's supervision of RMB cash. Keke Kuang(2011) believes that with the deepening of the internationalization of the RMB, it will increase the difficulty of regulating the RMB cash stock and reduce the independence of China's implementation of monetary policy. At the same time, the offshore RMB business also restricts China's implementation of monetary policy effectiveness (Jianyu Mei, Hua Chen, 2017) (Li Liu, Yiming Wang, 2005).

\section{The theory of RMB internationalization and monetary policy}

\subsection{The concept of RMB internationalization}

The internationalization of RMB means that it can cross national borders and circulate abroad, becoming the internationally recognized process of pricing,settlement and reserve currency. 
Although the current circulation of RMB does not mean that it has been internationalized, whose expansion of overseas circulation will inevitably lead to the internationalization of the RMB, making it become the world currency (Yanzhi Fan, Wei Yang, 2016).

The internationalization of RMB includes three aspects: first,it is liquid abroad; second, the financial products that become the major international financial institutions are denominated in $\mathrm{RMB}$; last, the economic and trade settlement in must meet certain requirements. This is a common standard for measuring the internationalization of RMB. The last two points are the most important.

\subsection{The concept of monetary policy and monetary policy effects}

Monetary policy is a very important part of national macroeconomic policies. The choice and implementation of monetary policy will affect issues such as money demand and money supply. Monetary policy refers to the general term of the various policies, which are adopted by the People's Bank of China to control and regulate the money supply and credit volume to achieve their specific economic goals. In fact, monetary policy including various tools will be used by the state to regulate the money supply to regulate market interest rates, and influences investors' investment in capital through changes in market interest rates. The three magic weapons which regulate the supply of demand for monetary policy tools are the deposit reserve ratio, open market operations and discounting policies (Yutao Wang, 2017).

The effect of monetary policy refers to the impact of changes in the money supply on aggregate demand and thus on national income and employment. The effect of monetary policy can be measured in two ways. First, in terms of quantity, it is used to measure the size of monetary policy, that is, the quantitative effect of monetary policy; second, in terms of time, it is used to analyze the speed of monetary policy, that is, the time effect of monetary policy. Therefore, the effect of measuring monetary policy is to analyze and measure the effectiveness of monetary policy to solve social and economic problems, and how long it will take effect after the policy is implemented.

\subsection{The mechanism of RMB internationalization on monetary policy}

The spillover effect of monetary policy means that in the context of the continuous integration of the international economy, the economies of each country are interacting and relying on each other. You have me, I have you, and a country's monetary policy changes easily. It has an impact on the economies of other countries (Keke Qi, 2011). The spillover effects of monetary policy include positive spillover effects and negative spillover effects, which refer to the good and bad effects of one country's monetary policy on other countries.

The spillover effect of monetary policy will lead to the implementation of China's monetary policy, the influence of the policy will only be partially exerted, and the monetary policy of other countries will affect China's economy in turn, thus affecting the effectiveness of China's monetary policy. Therefore, it is our duty to reduce the negative impact of the implementation of the RMB policy, so as to give up the maximization of its own interests under certain circumstances.

The interest rate is an important means for a central bank to control the amount of credit (Rui $\mathrm{Li}$, 2015).After the RMB was internationalized, the RMB needed to consider the demand for circulation abroad. Therefore, the factors affecting interest rates became more complicated and diverse, and the interest rate was set. Time should not only consider the impact on the country, but also the impact on foreign countries and the impact of foreign interest rates on China. With the deepening of the internationalization of the RMB, the market demand for the RMB is constantly expanding, and the market interest rate is also constantly rising, resulting in the continuous appreciation of the RMB. After the internationalization of the RMB, it is more difficult to use interest rates to regulate the price level. At present, China is carrying out comprehensive reform of 
the interest rate market. The interest rate before the reform is decided by the central bank of China. After the reform, the interest rate is determined jointly by both the market demand and the supply. Therefore, this also greatly weakens the independence of monetary policy (Xiancang Fang, 2013).

When China adopts an expansionary monetary policy to achieve domestic economic growth with the internationalization of RMB, which will bright both effects to us. On the one hand, low interest rates can stimulate household consumption and corporate investment. On the other hand, low interest rate policies will reduce the rate of return on RMB, leading to the large-scale outflow of funds, and ultimately the expansionary monetary policy can not achieve the intended goals, and will shake the confidence of the RMB holders.

The supply of domestic currency has risen, and the interest rate of the country's internal currency has fallen. On the one hand, for all aspects of fund projects, the flow of funds to other countries has led to an increase in the value of foreign exchange, and the domestic currency has depreciated. On the other hand, at the price of goods. In terms of competitiveness, the prices of domestic goods have risen, the competitiveness of foreign exports has been weakened, the value of foreign exchange has risen, and the value of domestic currency has fallen. As the value of RMB has fallen, it has returned to competitiveness and demand has also improved. At the same time, the number of items exported to the outside world has also increased. The balance of income and expenditure of the international community can be achieved, and the disposable income of the people has also increased. In addition, the influence of the RMB on the international community will also fall. If the operation is not appropriate, it will affect financial market. Therefore, if the degree of internationalization of RMB continues to increase, the effect of monetary policy will become smaller and smaller.

When the RMB is internationalized, the domestic currency will decline in other countries, but the overall demand is increasing, so the people's demand for money is increasing. The source of demand for money comes mainly from three main motives: trading motives, prevention motives and speculative motives. Assuming that the supply and demand of money are not balanced, economic and social development will be affected, resulting in many adverse consequences such as inflation, reduction in monetary policy effects (Jinwen Wu,2014).

Before the RMB has been widely circulated around the world, the supply of money in China is usually regulated and managed by the central bank, and interest rates have little impact on it. When the RMB is widely circulated around the world, China's money supply is mainly determined by the supply of the RMB offshore market and the supply of China's financial market. In China, when the money supply market and the offshore RMB market are superimposed, the trend of the curve of the money supply function will be tilted to the upper right. That is to say, when the interest rate of China's currency increases, the money supply will increase.

\section{The Status QUO of China's Monetary Policy and RMB Internationalization}

The "moderately loose monetary policy" currently implemented in China is to relax monetary policy and increase the money supply to stimulate consumption, investment and production. The tools adopted are mainly to decrease interest rates, the bank deposit reserve ratio and rediscount rate, and to reduce the open market. The intensity of operations, while encouraging bank credit and other means, is to increase market liquidity. From the situation in the first quarter of 2017, monetary policy remains "stable and neutral", as follows: First, the growth rate of broad money (M2) supply has declined for five consecutive months since October 2016, but in 20172 The month has risen and fell again in March (Dexu He,Jie Zhang,2017). Second, in order to strengthen the ability of financial institutions to adjust their structure, various financial institutions in China have made the benchmark interest rates lower for RMB loans and deposits.

At the end of 2016, RMB ranked the sixth largest payment currency in the world; the 
cross-border use infrastructure of RMB was further improved. At the end of 2016, the construction of the RMB cross-border payment system was further promoted and directly involved in the expansion, further standardizing and improving the management of RMB cross-border payment and payment information. System business rules to improve data quality. In October 2016, the RMB was officially included in the monetary basket of the International Monetary Fund's Special Drawing Rights (Rubin Chen, 2016). This is an important milestone in the internationalization of $\mathrm{RMB}$, marking the beginning of a new stage of internationalization of the RMB. In 2017, the international use of the RMB was steadily advanced, and the RMB maintained a stable position in the global monetary system. In 2018, the degree of internationalization of the famous currency has accelerated. Recently, the rapid increase in the money supply has caused widespread concern in the Chinese market, and the related regains internationalization of the RMB to it has also received global attention. According to the statistics of the Global Banking Financial Telecommunications Association, the internationalization of the RMB will continue to be solidly promoted in 2018, maintaining the stable position of the RMB in the global monetary system.

\section{The implementation effect of China's monetary policy}

The first is to promote the marketization of interest rates and reform the foreign currency management system. With regard to the improvement of China's interest rate market-oriented management system and the opening up of the economy, the People's Bank of China decided to adopt foreign currency interest rate management measures. It mainly includes: foreign currency loan interest rate, deposit interest rate of small foreign currency, etc., which are uniformly regulated by the banking industry and uniformly implemented by financial institutions in China.

The second is to improve the construction of the personal credit system and implement the real-name savings system. By regulating savings behavior, the establishment of a personal credit system can be strengthened, and the People's Bank of China decides to implement a real-name system for savings deposits.

The third can promote commercial banks to innovate in the variety of financial services. The People's Bank of China and the China Securities Regulatory Commission jointly issued a document promulgating the Measures for the Administration of Pledged Loans of Securities Companies, allowing commercial banks to obtain loans from securities companies for stock pledge.

Fourth, strengthen the guidance of credit policy and control the flow of funds. The People's Bank of China issues a document to allow financial institutions other than the Postal Savings and Remittance Bureau to open "education savings deposits" and exempt interest income tax;

The fifth is to promote the establishment of currency marketization. Allow Chinese securities companies to conduct capital business with the domestic bank market.

\section{Conclusion and countermeasures}

Improve supply monitoring statistics and interventions. After the internationalization of RMB, the domestic monetary authorities and the offshore market of RMB are two factors that have an impact on monetary policy, which will lead to more cumbersome statistics on money supply. Therefore, it is necessary to properly improve the monitoring system of money supply so that it can accurately and accurately calculate the amount of RMB flowing across borders, thus ensuring that China's monetary policy is more independent, reasonable and efficient.

Further reforming the financial market. As the degree of internationalization of RMB has further deepened, the current financial market has seen fewer investors. The development of general capital operation market construction has accelerated the circulation of monetary funds on a global scale, making the development of financial markets lacking certain activity and liquidity. Not conducive 
to the development of China's real economy. Therefore, it is imperative to accelerate financial market reform. On the one hand, we must accelerate the construction of multi-level capital markets and satisfy the needs of investors with different preferences. On the other hand.,focus on cultivating more rational investors and promoting the activeness of financial markets.

Reasonable supply of money. Rational and effective regulation of the money supply, so that the supply speed is compatible with the overall national strength and international status. At present, the degree of internationalization of RMB is still in a deepening stage. Therefore, the money supply should be commensurate with the overall national strength and international status, so that the pace of the money market and the commodity market should be consistent. It is necessary to timely regulate China's monetary policy and effectively solve RMB international. The problem of money supply caused by the reform, keeping the money supply stable can also effectively alleviate China's inflationary pressure and stabilize prices (Hongqing He,2012).

The internationalization of RMB has brought us opportunities and challenges, which have brought many potential advantages, affecting the independence, effectiveness, and conductivity of China's monetary policy, and at the same time exacerbating the negative spillover effects of China's monetary policy. Therefore, China must implement a loose exchange rate system, and must face the problems of Triffin, currency substitution, and money demand. Faced with the adverse effects of these monetary policies, we propose to improve the supply of monitoring statistics and interventions, further reform the financial market, and rational supply of money supply and other countermeasures.

\section{References}

[1] BenjaminJ Cohen, 2012. The Yuan Tomorrow? Evaluating China's Currency Internationali sation Strategy [J]. New Political Economy. 3, pp. 126-128.

[2] Shabtai Donnenfeld, AlfredHaug, 2003. Currency Invoicing in International Trade: an Empirical Investigation [J], Review of International Economics .2, pp.36-39.

[3] Marco Airaudo, 2014.Currency substitution risk premia and the Taylor principle [J], Journal of Economic Dynamics and Control. 4,pp. 26-28.

[4] Jianyu Mei, Hua Chen, 2017. The Impact of RMB Internationalization on the Effectiveness of Monetary Policy [J], Journal of Southern Economy. 4, pp.23-24.

[5] Li Liu, Yiming Wang, 2005. Analysis of the Effect of Monetary Policy under the Internationalization of RMB [J]. 8, pp.1-6.

[6] Yanzhi Fan, Wei Yang, 2016. Analysis of the Meaning and Conditions of RMB Internationalization [J], Fortune Today. 6, pp.12-15.

[7] Yutao Wang, 2017.Analysis of Macroeconomic Policies in China's Economic Crisis [J],Zhifu Times. 4, pp.32-34.

[8] Keke Kuang, 2011. The Impact of RMB Internationalization on China's Monetary Policy [J], Financial Theory and Practice.11,pp.66-70.

[9] Rui Li,2015. Analysis of the Impact of RMB Internationalization on China's Monetary Policy [J], Foreign Trade and Economic Cooperation. 9, pp.24-25.

[10] Xiancang Fang,2013. The Influence of RMB Internationalization on the Transmission of Monetary Policy [J], Journal of East China Normal University (Philosophy and Social Sciences). 6, pp.65-66.

[11] Jinwen Wu,2014. The Impact of RMB Internationalization on China's Monetary Policy, Master's thesis of East China Normal University. 5, pp.21-25.

[12] Dexu He, Jie Zhang, 2017. The Status Quo and Choice of China's Monetary Policy [J], China Economic Report.6, 47-49.

[13] Rubin Chen, 2016.Analysis of the Causes of the Change of Potential Output Growth Rate in China [J], South China University of Technology Doctoral Dissertation.5, pp.15-16.

[14] Qinglong Zhang, 2011. Analysis of the Impact of RMB Internationalization on Monetary Policy, Learning and Research. 7, pp.11-12.

[15] Hongqing He, 2012. The Risk of RMB Internationalization and Its Prevention [J], Journal of Yan'an University (Social Science Edition). 6, pp.95-96. 